\title{
THE HOMERIC POEMS AND THE CONCEPT OF TRADITION
}

\author{
Gustavo Junqueira Duarte Oliveira ${ }^{1}$
}

\begin{abstract}
This paper focuses on the poetical tradition to which the Homeric poems belong. Firstly, I present a theoretical discussion regarding the concept of Tradition. The emphasis is on the transmission of content thought as relating to the past of certain groups, as well as the specific ways in which those groups value such elements. Secondly, the paper presents an interaction scheme between different aspects inside one tradition, or between different traditions. Finally, in the main section of the paper, I discuss the tradition the Homeric poems belong to, as well as the role the poems play in it. This discussion covers several phenomena that can be identified with the tradition, from the poetical ones, such as the Greek hexametrical poetry, to the iconographic ones, especially vase paintings from the eighth century ${ }^{2}$ onwards. I conclude with a brief discussion on how the Homeric poems can be used as testimony to this broader tradition.
\end{abstract}

\section{Keywords}

Homer; Greek poetry; tradition.

\footnotetext{
${ }^{1}$ Associate Professor, Faculty of São Bernardo do Campo - São Bernardo do Campo, SP, Brazil. email: gustavojdo@gmail.com

2 I would like to thank Tatiana Faia, Camila Aline Zanon and Ana Paula Bezerra Severiano for many invaluable suggestions and corrections that improved the present paper. All the references to centuries in this paper refer to periods before the Current Era, save mentions to the contrary.
} 


\section{Resumo}

O tema deste artigo é a tradição poética da qual os poemas homéricos fazem parte. Em um primeiro momento, propus uma discussão teórica sobre o conceito de tradição. Enfatizei os aspectos da transmissão de determinados conteúdos pensados como relacionados ao passado de determinados grupos, bem como a valorização específica destes elementos por estes grupos. Em seguida, busquei apresentar um esquema de interação entre aspectos diferentes no interior de uma mesma tradição, ou entre tradições diferentes. Na parte principal do artigo, delimitei a tradição à qual os poemas homéricos pertencem e a posição que nela ocupam. A discussão aqui proposta abrange a apresentação de vários fenômenos que podem ser identificados com esta tradição, desde os poéticos, como a poesia hexamétrica grega, até os iconográficos, em especial na pintura de vasos a partir do século VIII ${ }^{3}$. Por fim, o artigo se encerra com uma pequena discussão sobre como os poemas homéricos podem ser vistos como testemunhos desta tradição mais ampla.

\section{Palavras-chave}

Homero; poesia grega; tradição.

\footnotetext{
${ }^{3}$ Agradeço a Tatiana Faia, Camila Aline Zanon e Ana Paula Bezerra Severiano pelas sugestões e correções que em muito beneficiaram este artigo. Todas as referências a séculos neste artigo dizem respeito a períodos anteriores a nossa era, salvo indicação do contrário.
} 


\section{The concept of Tradition}

a) What is tradition?

I should begin this paper with a warning. I do not intend to define tradition in a manner that covers the multiplicity of uses the concept allows, such as the relation between tradition and modernity, or the invention of traditions. Those types of approach will be mentioned, but their details can be found on studies made by Shiels (1981) and on collections made by Hobsbawm and Ranger (1997) or Phillips and Schochet (2004). My objective here is to explore an idea of tradition that relates to a specific type I intend to investigate. Even so, I expect that what is presented here could be useful to researchers of other areas. Studies that strive to define this concept in a broader fashion or a narrower one are still lacking.

Initially, what I understand by tradition is a phenomenon that transmits through time characteristics and contents related to a human community. The members of such communities preserve those elements by an effort that goes beyond simple repetition. Associated to the transmission itself is a specific type of appreciation, generally a positive one, of the elements being transmitted.

In his definition of the concept, Shiels starts by stating that the concept can have multiple meanings. The most basic one is that of anything of the past transmitted to the present (Sheils, 1981: 12-17). Many traditions have a normative element, a belief or behavior model that should be enforced. The normative aspect can be an inertial force that helps to bind a society together throughout time (Sheils, 1981: 23-25).

According to Lenclud, however, the concept usually lacks a proper clarification. One of the main aspects of its uses is, initially, an association of the word tradition with time. This relation evokes adjectives like ancestral, or even immemorial. A tradition represents something of the past that persists in the present. The idea represented by tradition is, therefore, one of antiquity and of a continuity that seems to be maintained in an uninterrupted fashion (Lenclud, 1994: 26-29).

Many scholars consider this approach insufficient. A tradition is not always created by its antiquity. One could formulate the opposite: a tradition fabricates a feeling of antiquity. Lenclud states that for many scholars the idea of tradition is determined by the present, not by the past. It is the notion of the invention of traditions, according to which a tradition is an answer, found in the past, for questions formulated in the present. A 
tradition would be a rhetoric of what should have been, in a retrospective point of view (Lenclud, 1994: 29-34).

Such a perspective has become notorious since the collection of papers organized by Hobsbawm and Ranger, published in 1983. In the introduction, Hobsbawm defends that an invented tradition tries to establish a continuity with the past, one that can function very artificially. Invented traditions would be reactions to new situations that take shape in reference to what is thought as past contexts (Hobsbawm; Ranger, 1997: 9-12).

In response to the approach proposed by Ranger and Hobsbawm, Phillips and Schochet also organized a collection of papers in 2004. In the introduction, Phillips questions the concept of tradition privileged by Hobsbawm, considering that all traditions are invented, and all longstanding tradition goes through a process of continuous reinventing. For him, a simple opposition between a true tradition and an invented one is not possible. Being so, the approach Hobsbawm defends reflects a notion that a tradition should be involuntary and unconscious to be genuine. For Phillips, a tradition is not necessarily static or reactionary, but something that can be adaptable, constructive and creative. Deliberate actions to revive or to keep traditions alive are not necessarily inventions of new traditions (Phillips; Schochet, 2004: 4-7).

Schochet, in the final chapter of the collection, proposes that it is also important to distinguish the position in which the subject is in relation to a tradition. An internal perspective is related to its participants, people that act in accordance to it. To an external observer, the use of the tradition is descriptive and explanatory. The internal commentary of the tradition is more prescriptive, a way to enforce certain practices (Phillips; Schochet, 2004: 305).

Once again, Lenclud suggests two manners to comprehend the relation a subject can have with a tradition: that of cultures in which the heritage of the past is produced in the present, without any awareness of the process, and without a knowledge of the possibility to choose to break with such process. It becomes an acritical consumption of the tradition. The other manner, the modern one, puts the past at a distance, by means of knowledge. The subject can see the tradition by the exterior, and even problematize its relation to the past (Lenclud, 1994: 42).

For the purposes of my discussion, it is the first type suggested by Lenclud which is at stake. The tradition I will debate does not belong to a context in which there is a consciousness of the existence of a choice to 
break with this process. I do not agree, however, that it represents a mere acritical consumption of elements conceived as belonging to the past. In the case of the oral epic hexametric poetry, such elements are specifically valued, worked and transmitted to reach certain effects. Here I follow the theorization of another group of scholars.

According to Outhwaite and Bottomore, tradition is communally associated to practices that reach considerably into the past and display a kind of sacred aura. The word is derived from the Latin verb tradere, which means to deliver, to transmit, to legate to the next generations. It could refer to the transmission of trivial things, but it was then reserved to the deposits of the past that are of relevant value to the present. Traditions belong to the most important and valued spheres of human life. Less relevant things being transmitted can be labelled "habits" or "folklore" (Outhwaite; Bottomore, 1996: 777).

Highlighting some aspects already mentioned Seligman and Johnson understand the use of the word tradition as being associated to a judgement of value of what is transmitted. Some habits, although they are also transmitted, are received in a passive manner, without having its values reinforced. Something that is transmitted only becomes a tradition when its antiquity is recognized, and there is a desire to keep it. In this way, it must have associated with it a judgment of value, and not only a repetition. The maintenance of a tradition is the enforcement of this judgment (Seligman; Johnson, 1957: 65-67).

Efforts to preserve ancient forms can be associated to inertia or to conservatism, but when they bring a conscious judgment of value that considers that the old ways are better, that it is a living tradition. Notwithstanding, a tradition does not necessarily operates through conservatism. Innovation can occur and be incorporated or even create other types of tradition, if accepted. Innovation can also be seen as a source of corruption and be opposed (Seligman; Johnson, 1957: 65-67).

Central to my argument are the notions of transmission and appreciation, as discussed in these definitions of the concept. That means that, as Francisco suggests (Francisco, 2012: 2-3), tradition is not simply a formal repetition of what is being transmitted. It is an engaged support, accomplished by a value judgment made by the very agents that perform the transmission process. Those social agents may not consider ways to escape the tradition, but they certainly do not transmit it uncritically. More than a value judgement, the maintenance of a tradition is not related simply to some static process of conserving past elements. New forms can be associated to what is considered traditional, if they are 
valued or understood as effective and reverberating a belief in its supposed antiquity. It is not necessarily an invention of a tradition, but a reinterpretation of those past elements from the point of view the present has about its pertinence.

When they are genuinely ancient, and such is the case of the traditions I will deal with in this paper, they can be though as long-term phenomena, following the Braudelian concept (Braudel, 2009). Such phenomena would operate as a way to integrate temporal contexts, in which the social actors share the appreciation of what is understood as traditional.

b) The concept of multiple and interconnected traditions: traditions inside traditions

As long-term phenomena that display continuity, but permeable to transformation, sometimes traditions adopt new elements and change so much that we can say new types of traditions are born inside them. That does not mean that the original tradition is necessarily abandoned, but that new manifestations are accepted. It could be said that they gain a life of its own. However, it is not that they are Ranger and Hobsbawm's invented traditions. Alternate forms of tradition could embrace, include or just interact with one another. Besides, they could follow or coexist parallel to each other, as contemporary phenomena. A researcher could trace a typology of traditions and their transformation throughout such processes.

Firstly, there is what I call originating traditions. They are the starting point of other traditions that derive from them. They can be real traditions, historically attested, or even logical principles, mere abstractions.

I call derived traditions the phenomena that develop from originating types. However, sometimes a derived tradition can originate different forms itself. In such instances, I call the new forms indirect derived traditions, originated from direct derived traditions. Embracing all those forms is a broader tradition. It contains all the other phenomena mentioned, from the original to de derived (direct or indirect). All this can be represented in an explanatory diagram: 


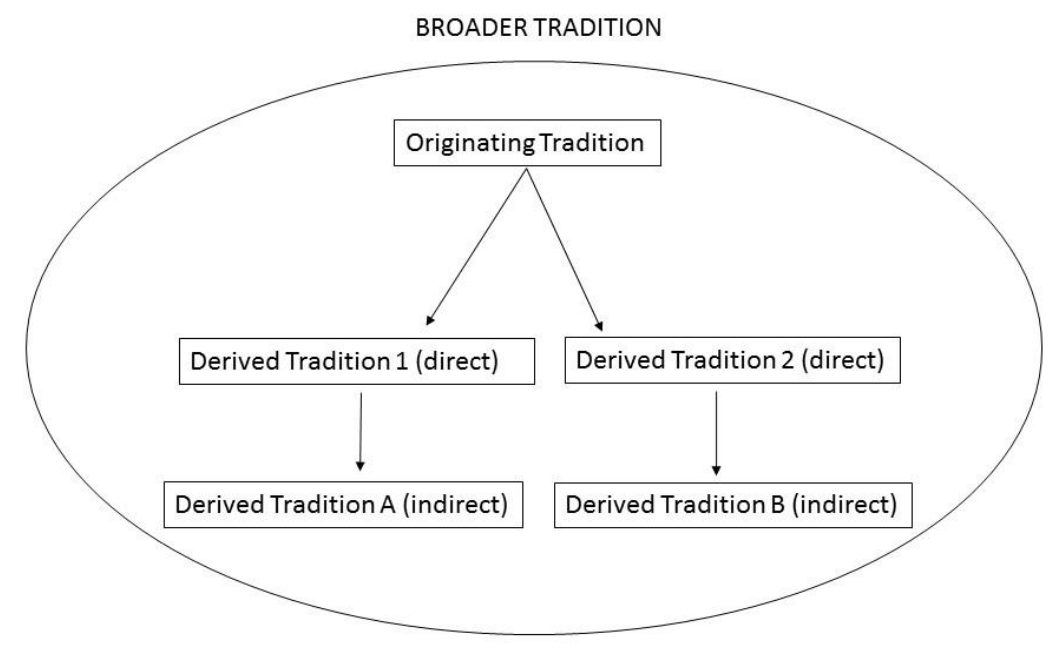

Diagram 1

Nevertheless, the diagram proposed above could ultimately lead the researcher to think of traditions as a static phenomenon. What can usually be observed is that there is no one-way interaction between those forms. A tradition that precedes another can itself be influenced by a derived phenomenon, adopting new ways of traditional transmission. Besides, a type of tradition could have more than one originating element. The game of interactions and influences is far more complex than the static diagram displayed above could contemplate ${ }^{4}$. Perhaps a second diagram could be more comprehensive:

4 Shiels presents several interaction processes between traditions, such as by addition, amalgamation, absorption, fusion, as well as dissociating processes like ramification or disaggregation. 


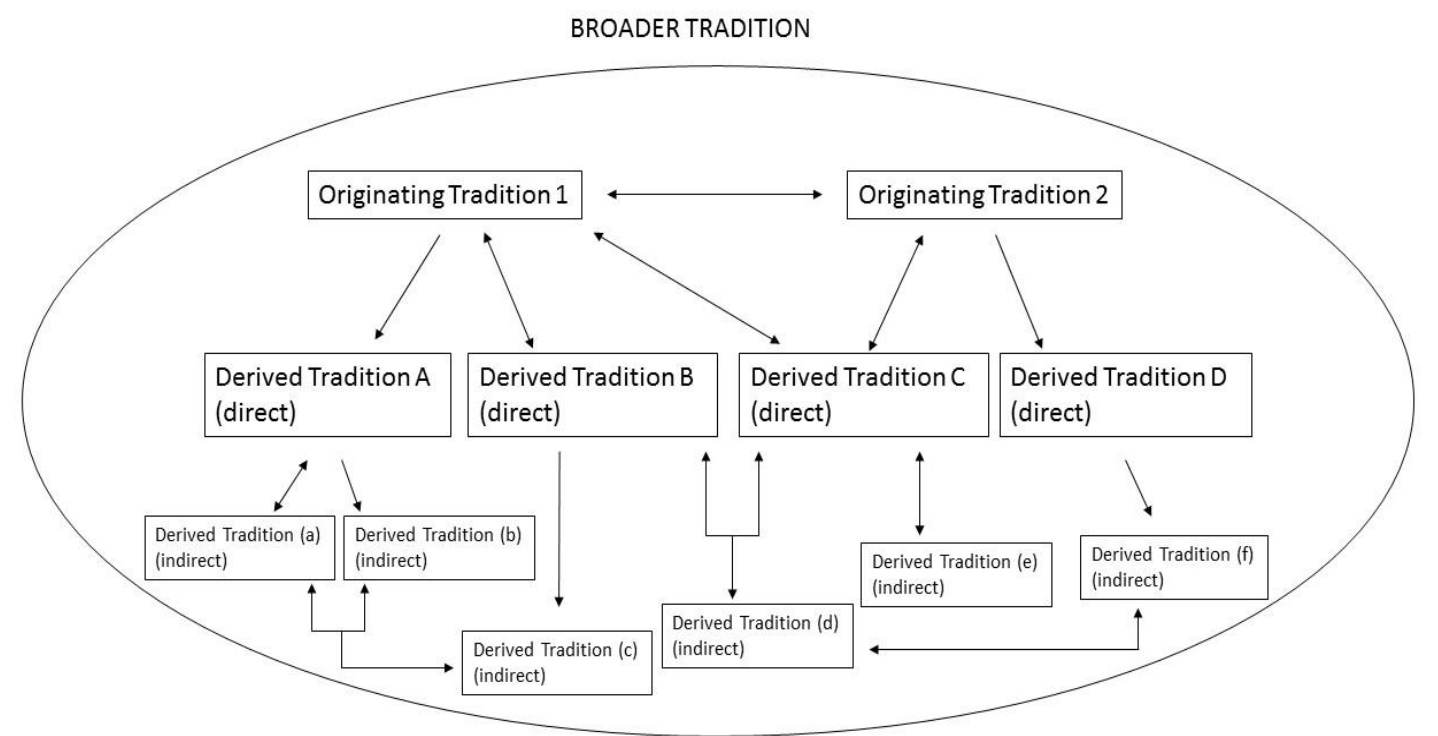

Diagram 2

c) Transmission and creation of stories belonging to a heroic and mythical past in the Greek Tradition

The argument I would like to present here relates to a specific tradition. It is the ancient Greek tradition of transmission and creation of stories related to a heroic and mythical past that includes, but is not limited to the Homeric poems ${ }^{5}$. This tradition contains, thematically, a number of elements: from the creation of that world, passing through the organization of the gods, to the Age of Heroes. It could be transmitted in many ways: oral transmission in several types of verse or without versification; images in figurative art; written text; etc.

This tradition, diachronically, would embrace the originating context of those creations, may them be real historical context or logical principles that are not historically attested. It would also embrace the purely textual transmission of written texts and the maintenance and cataloging of images nowadays. It consists on a very long-term tradition. It is important to emphasize that. This tradition, although greatly

\footnotetext{
${ }^{5}$ According to Scodel, the concept of tradition is relatively little discussed by specialists of Homer. It is generally used, diachronically, to refer to stories and their processes of transmission. It can also be used, synchronically to imply the rules of the genre and its conventions, like the poetic dialect, the formulas, the themes, the metric, the narratives, and so forth. The problem is that, instead of defining what tradition is, the Homerist tend to reify it.
} 
transformed, lingers almost uninterruptedly as relevant to each of its contexts in a particular fashion.

Those transformations it went through can be observed since Antiquity. For instance, the transmission of poetry itself went from oral to written in Ancient times. It is, as I said, a very ancient tradition, if we use the broader sense of the term. It integrates those contexts that are most distant in time, whose particularities we can only speculate about, into the most recent contexts. The modern critical studies and even the adaptations of Greek mythological and epic stories on recent pop culture can be thought as part of the same millenary tradition. It is true that on each moment of this long process the way the tradition is valued and the very forms of transmissions can vary greatly, even within the same historic context. Still, this longevity is a very important aspect.

d) The tradition of transmission of stories in Greek epic hexametric poetry (oral and written transmission)

Drawing on this delimitation of our specific tradition, I would like to reach another definition. The tradition I am most interested in is that of the transmission of such content in Greek epic hexametric poetry. There are more than one possibility of transmission at stake in this tradition. There is the oral transmission, on one hand, and written transmission, associated to fixated texts, on the other. This is another long-term phenomenon. Even today, besides the manuscripts that are still available and preserved, the practice of establishing different editions of the texts in Greek epic hexametric poetry remains ${ }^{6}$. This practice attests to the fact that the tradition of text transmission I am dealing with is still alive.

This tradition is socially relevant, in its own fashion, to each context. Each moment brings its own specificity and raises aspects of interest. That is why the concept must be further defined.

e) The transmission tradition of Greek oral epic hexametric poetry

I finally reach the last delimitation of the tradition I am interested in. Inside all the layers of tradition I have presented, there is the tradition of transmission of Greek oral epic hexametric poetry. The focus can be narrowed even more, if I choose to include only two of its members: the Iliad and the Odyssey, the so-called Homeric poems.

\footnotetext{
${ }^{6}$ To mention only a few, the texts of the Iliad and the Odyssey, edited by Monroe and Allen (1920), are still largely influential. Thiel $(1996)$ and West $(1998,2000)$ have both presented recent editions of the Iliad. The same Thiel (1991) edited the Odyssey in the end of the twentieth century.
} 
Several difficulties emerge from this selection. The main ones are related to the fact that we only have access to written texts of that tradition. Still, they are filled, according to the most accepted theories nowadays, with deep traces of orality ${ }^{7}$. On the remainder of this paper, I will map the main characteristics of this tradition.

\section{The tradition of the Homeric poems}

a) The themes

Despite its specificities, one aspect of the tradition must be highlighted. It puts the Homeric poems in relationship to other layers of the broader tradition. Usually, despite the approaches adopted by scholars and the assumptions made as to the dating criteria, most researchers accept that the poems have not emerged from the vacuum, but belong to an older and broader tradition 8 .

It has been suggested that the poems were the result of the genius of a master poet, that composed the Iliad and the Odyssey, or alternatively, a master poet for each poem. This poet could have composed orally, but his poems were memorized by followers that would afterwards quote more or less accurately the works of their mentor9. Likewise, the poet could have had the help of scribes that wrote down what was dictated in the moment of composition ${ }^{10}$. Another possibility is that the poems were already composed with the use of writing ${ }^{11}$. Yet another possibility is that the poems were the result of the merging of several smaller poems of diverse origins, edited by a compiler ${ }^{12}$. The poems could also have originated from oral composition and re-composition that took place over long periods of time, with vast spatial reach, and undertaken by different singers ${ }^{13}$. Some scholars have suggested that the poems are not even representative of their tradition, due to its superior aesthetic quality, structure, complexity, size and planned unity ${ }^{14}$. Finally, it has been suggested that the Homeric poems actively and conscientiously counter

\footnotetext{
7 This approach is greatly indebted to the ideas of Parry (1930; 1932) and Lord (1960).

${ }^{8}$ Even authors that are critics of the oral theories, such as Ahl and Roisman, defend that the poems are part of a wider mythical tradition (Ahl; Roisman, 1996: 16-18).

${ }_{9}^{9}$ Position defended by Kirk (1962) and Taplin (1992).

10 Position defended by Jensen (1980), Shear (2000) and Lord (1960).

11 Position defended by West $(2011,2014)$ and A. Parry (1989: 137).

12 Position defended by Analists like Wilamowitz (1991).

${ }^{13}$ Position defended by Nagy (1996).

${ }^{14}$ Rutherford wonders if the Iliad and the Odyssey would represent a typical form of the epic tradition or its final exponent (Rutherford, 1996: 5).
} 
the tendencies preserved by its tradition, adding innovations to the development of its plots ${ }^{15}$.

Despite the positions, or combination of positions, defended by the scholars on one or other point of that spectrum, a broader tradition that existed independently of the Homeric poems is assumed. Even if they came into existence as a way to counter such tradition, the poems are constructed to make clear that they are part of a bigger whole. The focus, in the Iliad and in the Odyssey, is narrowed to specific plots. Nevertheless, in several moments the poems evidence the assumption that the audiences or readers should recognize this wider universe. This universe contained other episodes, other characters and, possibly, other versions of the stories that are preserved in the Homeric poems.

So, what is this broader tradition? Moreover, where are the vestiges of its presence, beyond the poems themselves? As I have been trying to demonstrate, the concept of tradition can be used to name different but interconnected phenomena. Here the relevant tradition is the broader one. It deals with the transmission of stories, myths and episodes that involved characters that are a part of the formation and ordering of the Greek world, as well as part of its Heroic Age. In Antiquity the tradition related to this heroic past, on many occasions, was seen as historical truth, as part of the real Greek past.

The heroic past was populated by characters that were involved in great many episodes, fighting monsters (like Heracles, Perseus or Bellerophon), travelling and taking part in adventures (like the Argonauts) or fighting in wars, like the ones in Thebes or Troy. The Iliad and the Odyssey are related to this last type, especially associated with the war and return from Troy.

Therefore, the broader tradition represents a vision a certain people had of its heroic and mythical past. More than that, the tradition is related to the transmission of that vision. The Iliad and the Odyssey are part of it. The Hesiodic poems, the Homeric Hymns and the poems of the Epic Cycle, that survived only as fragments or summaries, are as well.

Homer and Hesiod ${ }^{16}$ in special were considered authorities on the gods, on the heroic past and on the history of the cosmos, according to Graziosi and Haubold. The poets shared not only a technique and the tools of the epic hexameter, but a view of the world and how it has changed in time

\footnotetext{
${ }^{15}$ Position defended by Russo (1968).

${ }^{16}$ I will use the term "Homer" to indicate not necessarily an actual poet, but the Homeric poems themselves. The same goes for "Hesiod" and the Hesiodic poems.
} 
(Graziosi; Haubold, 2005: 8). However, this was not the only form of transmission of this vision of the past.

Vase painting and other forms of figurative art also registered the circulation of this tradition, often in different versions, independent of the epic poems. They were, nevertheless, part of the same context ${ }^{17}$. The cult of Heroes and their tombs - although having a different origin related to the cult of the ancestors in local perspectives - sometimes also associated themselves with this tradition, using its heroes as objects of cult ${ }^{18}$.

Despite being independent, those forms of transmission - poetry, figurative art and heroic cult - could also interact. The variations inside the broader tradition could create derived traditions on itself, linked by some characteristics, but independent in others, as I have proposed.

For now, my first assumption must be made clear. The Homeric poems exist inside a wider complex, which I call tradition of transmission. This tradition includes a vision of the past that can be compartmentalized in other forms of tradition. These other forms could also be delimited in relation to the content of this past (mythological or heroic) and in the fashion they were transmitted (figurative art, Hero cult, poetry and other forms of narrative).

b) The longevity of the tradition: when has it started?

Once the broader tradition is recognized and accepted, it is necessary to identify its temporal scope, its longevity. It is a very complex subject. To identify the beginning of the tradition is the hardest task.

An interesting approach would be to start by the dates concerning the epic scenes in figurative art. The first examples of scenes possibly related to epic themes begin to appear in the eighth century ${ }^{19}$. During this period, some other examples could be related to this tradition of transmission, but the identification of the scenes is less accurate ${ }^{20}$. What the figurative

\footnotetext{
17 Even if they were bounded to a particular way of transmission due to its materiality, the thematic parallelism attests to some kind of interaction between the different media. On the subject, see Malkin (1998: 38).

18 For a contrary perspective, see Seaford (1994: 180-181). Ainiam defends that the hero cult could function independently form the epics, and practices already in place could function as exempla that influenced the poetry (Ainiam, 1999: 33-35). In other words, the author accepts that there are interactions between the different forms of tradition.

19 According to Snodgrass, a transitory iconographic trend identified in six Greek regions probably presented the figure of the Siamese twins known as the Actorids. Snodgrass states that this trend had started in the middle of the eighth century and ceases to be present in the beginning of the seventh (Snodgrass, 2004: 42-62).

${ }^{20}$ For a survey of the scenes and the issues concerning them see Snodgrass (2004: 35-70).
} 
art can tell researchers about the dating of the tradition is that during this period, especially from the seventh century onwards, the circulation of the broader tradition was already in motion. Notwithstanding, it says little about its true origins, which possibly anticipates the examples known in figurative art in other media.

By using the benchmarks of the iconographic tradition of transmission related to the heroic and mythological stories, there is an indication that after the eighth century the tradition of epic hexametric poetry could also already exist, sharing similar themes. Nevertheless, the presence of heroic scenes in figurative art does not necessarily guarantee that the poetic tradition also began to circulate at that time. It is possible that the degree of sophistication in the Homeric poems required time to be fully developed.

A similar approach could be suggested by investigating the relation between some of the first alphabetic inscriptions and the broader tradition. There is a theory, championed by scholars like Powell (1996) that suggests that alphabetic writing was introduced in Greece to set epic poetry, like the Homeric poems, in that form. The fact that some of the oldest inscriptions are indeed written in hexameters might corroborate this hypothesis ${ }^{21}$.

In the case of poetry itself, dating the composition or fixation of the Homeric poems is a difficult task and the source of much speculation. The same applies to the Hesiodic poems, the Homeric Hymns and the Epic Cycle. The question of how to date them in relation to Homer is also a source of much controversy 22 .

One should tread carefully in this terrain. Due to the choice of themes and the possible survival of a series of characteristics related to material culture, political geography, language and even social structures, for some time a group of scholars has suggested that the heroic tradition and its poetry had its origins on the Mycenaean world. I have substantially dealt with this subject in a previous paper ${ }^{23}$. For now, it suffices to say that some elements of that world might have been preserved within the tradition during its processes of transmission. Although this notion is widely popular ${ }^{24}$, agreement is not unanimous. Raaflaub, for instance,

\footnotetext{
21 The precursor of this theory is Wade-Gery (1952: 11-14).

22 Janko's study is one of the most influential (Janko, 1982). There is also a recent volume organized by Andersen and Huag (2012).

${ }^{23}$ See Oliveira (2012).

${ }^{24}$ Its most radical defenders are Nilsson $(1932 ; 1993)$, Page (1976), Luce $(1975 ; 1998)$ and Shear (2000).
} 
criticizes it, and raises the possibility that the heroic tradition developed during the so-called Dark Ages of Greece ${ }^{25}$ as a way to explain the impressive ruins still visible at the time, supposedly connected to this previous heroic world (Raaflaud, 1998: 393-401). The fact that those ruins corresponded to Mycenaean structures would then be mere coincidence.

This is a hypothesis that should be carefully considered. Even if we accept the Mycenaean origin of some allusions to material vestiges in the poems, it is possible that these refer to family heirlooms, kept and treasured from generation to generation. They could also be associated with the same glamourous past of the impressive ruins ${ }^{26}$. On the other hand, we must also consider the possibility that this tradition has indeed begun in the Mycenaean world.

As I said, this is not the safest of terrains. One could emphasize that by the beginning of the seventh century the tradition of transmission of these heroic and mythological themes already existed in a developed manner, probably as result of a more ancient process. The reach of this process, on earlier centuries is the hardest thread to identify. On a narrower estimate, it might stretch as far as the end of the Greek Dark Ages and the beginning of the Archaic Period, between the ninth and eighth centuries. If a broader estimate is adopted, it could mean that the process stretches as far back as the Mycenaean world on its heyday and decline, between the fourteenth and twelfth centuries, or even further back. What leans to one extreme or the other can be summarized in two positions: the acceptance that the characteristics recognized as Mycenaean have indeed their origin in this context; the speculation that these elements entered the Homeric poems by other means.

c) The tradition's longevity: when has it ended?

The broader tradition of transmission of stories concerning the Greek heroes and myths never ended. As I said, it remains alive. However, this is not my subject here. The part of the tradition I am trying to delimit is linked to a specific context, or set of contexts. It is profoundly different from the types of transmission that still linger today. The ways in which modern contexts deal with such themes are not the same, nor do they have the same functions. The tradition, in its stages of development, is understood according to the particularities of each period in time. It is a

\footnotetext{
${ }^{25}$ Although very polemic, this term is still useful to designate the years between the Mycenaean collapse and the eighth century. The period is dark for the modern scholar, who has relatively few information about it. For a survey of the issue, see Desborough (1972: 11-12). Among contemporary archaeologists, the preferred terminology is Early Iron Age.

${ }^{26}$ See Grethlein (2010: 129).
} 
subject of interest for a researcher to understand why each epoch received and transmitted those phenomena in a particular way.

I shall use three criteria to approach the most recent limits of the part of the tradition I am dealing with here. The first one accounts for the ways in which agents within the tradition regarded its past and identified themselves with it, poetry being only one of the vehicles of this transmission process. Therefore, the first criterion accounts for how the tradition itself was regarded as an accurate mechanism of preservation of the past by the Greeks.

Nevertheless, this is not sufficient to set apart the layer of tradition we are dealing with. Even Strabo, in the first century A. D., considered Homer a reliable source of information about the heroic past ${ }^{27}$. That trust in Homer's reliability as a source went far beyond that. Notwithstanding, this is a first criterion: the tradition I am trying to delimit saw the heroic world as a real part of its past, this notion finds support in the perspectives of different authors such as Strabo, Herodotus and Thucydides 28 .

The second criterion deals with the oral transmission of this tradition in general, and the orally composed epic poetry specifically. For the purposes of my enquiry, I shall take into account the place of oral poetry in Greek society. Even with the introduction of writing in the eighth century, the oral forms of poetic communication were not immediately replaced.

If we consider the limits of literacy during this period, written forms of expression, even when culturally predominant, usually had the oral performance in mind when they were composed. Generally, they were written to be read aloud, possibly in public ${ }^{29}$. Still, some time during the fifth and fourth centuries, there can be detected a strong appreciation of the literate culture in the rhetoric of the elite. As for epic poetry and its tradition, from this moment onwards, the figure of the oral poet became associated, more and more, with a destitute man who only sung to the lower classes. Meanwhile, the elites had access to written epic poems ${ }^{30}$.

\footnotetext{
${ }^{27}$ For instance in Strabo I. 1. 2.

${ }^{28}$ Herodotus and Thucydides both state aspects linked to the Homeric narratives as being true, as in Hdt. I, 3-5, and Tuc. I. 3. 2-4; 9-11.

${ }^{29}$ According to Taplin, not even the starkest defender of the written composition of the Homeric poems would consider that they were composed for a literate public, to be read only silently (Taplin, 1992: 37).

${ }^{30}$ Jensen defends that this phenomenon can be observed from the fourth century on. The elites were progressively becoming literate and literate culture was more valued. The association of
} 
Parallel to the expansion of the written transmission of the epics, there is the rhapsode. Apparently, the rhapsodes transmitted the Homeric poems in a very different manner the earlier singers did. The rhapsodes were reciters of a theoretically fixed and established text ${ }^{31}$.

The third criterion is based on the association of the Homeric poems with the figure of an author, Homer, as we can observe from the sixth century onwards. On that period, his position as a revered author is also relevant. It is true that the name Homer can be a form of identifying the poetic tradition, as has been suggested by a number of scholars ${ }^{32}$. By this time, the Homeric poems were already considered classics. This benchmark is associated with the period when the poems started being transmitted as fixated texts, no longer being recomposed in performance. This way, possible oral reinterpretation of the poems was no longer transmitted to future generations.

As I interpret the vestiges left by the tradition of transmission of epic poetry, I would like to point out that there occurred a break in the appreciation of orality as a vehicle of the tradition. The status of the Homeric poems as classics, as authoritative texts, is very important, and that is how they reached modern times. However, the tradition I am striving to delimit is the one that allowed for other versions, variants, other poems, other episodes, other characters. In it, the singers were not put aside as marginal in a society that was becoming progressively literate. Still, although there were variations, the oral tradition of poetic transmission was in some level coherent and recognized as the same cultural phenomenon.

Even though the introduction of writing and its development happened in the same period I delimited and parallel to the tradition I am describing, the way I propose to identify the most recent limits of this poetic tradition of transmission is associated with the appreciation of oral composition and transmission as valued social and cultural forms. Therefore, the limit is attested on the existence of a written textual

oral culture with lower classes stronger. That was not the case earlier (Jensen, 1980: 125). See also Sealey (1957: 316, 342).

31 Burkert suggests that the rhapsodes substituted the singers. Creative improvisation was replaced by reproduction of a fixated text, learnt by heart and available in books. That would have occurred in the last third of the sixth century at the latest (Burker: 1987, 48-49). However, scholars like Jensen (1980: 116-122) and West (2010: 2) defend the hypothesis that the rhapsodes were still associated with creative composition, and not just fixed recitation.

${ }^{32}$ Among them Nagy (1996), in a tradition that goes back as far as the eighteenth century of the Current Era with Vico (2005: 873) and Wolf (1985). West suggests that a rhapsodic guild, the homeridai, could have adopted the two poems attributed to their mythic ancestor, Homer himself (West, 1999; 2014: 43). 
transmission of the epics that was predominant. This process can also be identified by the devaluation of oral forms of epic composition, relegated to a marginal status 33 .

With the development of the literate culture, the elite started to value other types of poetical elements more, relegating the oral culture to marginality. The singers would dedicate themselves to the entertainment of the lowest parts of the society. They now faced the competition of written texts, even those of the Iliad, the Odyssey, the Epic Cycle and the hymns. Oral Poetry would go from dominant manifestation to a marginal one. It would be associated to pure memorization, lack of creativity and genius, a phenomenon that influenced even part of the modern approaches to the subject.

d) The place the Homeric poems had inside the tradition: did they have an authoritative position?

On ancient times, the Homeric poems were already considered masterful examples of their tradition. Modern scholars have selected them as the great masterpieces of a whole culture ${ }^{34}$. They were pointed out as the best representatives of the tradition, but they have also been kept apart from it by their exceptionality 35 .

However, one must wait until the sixth century to find the name Homer mentioned in relation with epic poetry ${ }^{36}$. During part of Antiquity, other poems were associated with the name, but a process of exclusion implies a cultural preference, that relegates other poems to other poets and isolates the Iliad and the Odyssey as the great works of a genius: Homer. Nevertheless, this process seems to start relatively late ${ }^{37}$. Textual evidence from the sixth century shows that the name of Homer already appears as revered, and to some extent as the representative of the entire epic

\footnotetext{
33 See Jensen (1980: 125-127). According to Ford, already in the fifth century oral culture was diminishing and its older products were being evaluated by new language sciences, like rhetoric and philosophy (Ford, 1992).

34 See Rutherford (1996: 5).

${ }^{35}$ As by Davies (1989: 8-10).

${ }^{36}$ In the transition of the sixth to the fifth century Homer is mentioned by Heraclitus and Xenophanes, in passages preserved in later authors. Fragment 30 by Heraclitus is quoted by Diogenes Laertius, fragment 21 is quoted by Hippolytus and fragment 63a is quoted on the Iliad scholia A T XVII 251 and by Eustatius (on Marcovich's edition of 2007). The fragment 10 of Xenophanes is quoted by Herodian and fragments 11 and 12 are quoted by Sextus Empiricus (on Giannantoni's edition of 1993). For a survey of the older mentions and quotes of Homer, see Burkert (1987: 44) and West (1999).

37 According to Saïd, the Homeric corpus before 520 was considered wider. It included other epic poems, the Homeric Hymns and even epic parodies, besides the Iliad and the Odyssey (Saïd, 2011: 17).
} 
genre $^{38}$. This tendency continues into the fifth century, but there is a clear tendency to set apart the epics considered of greater quality in association with Homer, in detriment of other epics ${ }^{39}$.

In parallel to the one mentioned above, another process that also took place during the sixth and fifth centuries can be observed at work in figurative art. Until the sixth century, the artisans' preferences when choosing the themes for their works were not the episodes narrated in the Iliad or the Odyssey ${ }^{40}$. Even if one could argue that some scenes were inspired in episodes that are described or mentioned in the poems, what can be concluded is that the Homeric poems did not exert an authoritative influence on the choice of themes, nor in the establishment of which variant should be depicted, when thematic similarity was at stake.

The first element becomes clear if the preferred episodes are taken into account. The characters and scenes that are most popular are not central to, or do not figure at all in Homer. The second element is made explicit in face of the fact that even when the thematic choice corresponds to an episode mentioned in the poems, they do not follow for the most part the texts that were preserved accurately. The episode of Polyphemus, the cyclops, might be an exception, with examples that date back to $670^{41}$, but there is no proof that they were chosen because of the position that the Odyssey occupied within the tradition. It is likely that the artisans' preference was due to the episode itself, and not to the special position of authority the poem had ${ }^{42}$.

However, from the sixth century onwards, the episodes mentioned in the poems started to appear more and more, especially on vase painting. This process intensified during the $620 \mathrm{~s}$ and continued onto the next centuries $^{43}$. This is a strong sign that from that moment on, the poems, such as they were preserved or similar versions of them, increasingly began to be considered sources of authority to the choice of themes and

\footnotetext{
38 See Saïd (2011: 7) and Nagy (1996).

39 Graziosi and Haubold defend that this process seems to be fully developed in the fifth century, and accelerated even more during the Hellenistic Period. Progressively, the Iliad and the Odyssey were being set apart (Graziosi; Haulbold, 2005: 25-26).

40 On this matter, see Snodgrass (2004), Friis Johansen (1967), Lowenstan (1992, 1997), Touchefeu-Meynieur (1968), Powell (1992) and Burkert (1987).

${ }^{41}$ See Touchefeu-Meynieur, specially chart 1 (Touchefeu-Meynieur, 1968: 304).

42 For the opposite view, see Rutherford (1996: 17) and Thouchefeu-Meynieur (1968). Still, according to Malkin even on the fifth century, when there certainly existed texts of the Iliad and the Odyssey, the iconographic variants did not cease to exist. Variations are attested from the Geometric to the Roman period. That shows that those forms coexisted. These could comprise fixed texts, images, improvised songs, etc. (Malkin, 1998: 42).

${ }^{43}$ On this topic see, especially, Friis Johansen (1967: 223-230) and Malkin (1998: 41).
} 
versions of the episodes to be depicted. Even if they were not the only available sources. An interesting point to make is that this process coincides closely with the period in which the poems start to be more associated with the name Homer, setting the Iliad and the Odyssey apart from other epics. That process also appears to be a phenomenon that gained relevance on the sixth century. Prior to this period, if the poems existed in a fixated manner, they were not among the preferred sources that artisans and their costumers used to select versions and heroic episodes to be represented in figurative art.

e) Different types of poems within the Greek oral epic hexametric poetry

I outlined an idea of tradition that could be subdivided into several interconnected types, which are at the same time somewhat independent. Taking as a starting point this broader form of tradition, which includes the transmission of stories regarding the heroic past and the formation of the world of the gods, I have delimited the Greek epic oral hexametric poetry.

What is this poetic tradition, if one was to try to understand it beyond the Homeric poems? To answer this question one must necessarily deal with the issues of orality. Other types of Greek epic poetry were produced in hexameters in different epochs - works like the Argonautica by Apollonius of Rhodes. Nevertheless, they were composed with writtenbased poetic techniques ${ }^{44}$. The other poems mentioned in this paper, the Iliad and the Odyssey, the Hesiodic poems, the Homeric hymns and even the fragments of the Epic Cycle, despite their existence in writing, all carry with them possible signs of orality. If they were not entirely composed in an oral fashion, they have, at the very least, a more direct connection with that type of tradition. That does not mean that they are all of the same type. The size of each is a first characteristic that varies. The Iliad and the Odyssey individually surpass all of them in terms of extension. They are monumental when compared with the others ${ }^{45}$.

The themes also differentiate the Iliad, the Odyssey and the poems of the Epic Cycle from the others I mentioned. The Homeric Hymns seemed to function as introductions to the Homeric poems, even the more extensive ones. Besides, they carried narratives associated with the origins of each god, or important episodes related to them. The Hesiodic poems show, among other themes, the ordination of the world, its origins, eras and characteristics. In both cases, the Hymns and the Hesiodic poems, there

\footnotetext{
${ }^{44}$ See Parry (1930: 74).

45 The Cypria had eleven books. The Aethiopis and the Nostoi had five books each, and the Little Iliad four. The Iliou Persis and the Telegony had two each.
} 
are thematic congruencies with the stories developed in the Homeric poems, but it is important to emphasize the different approaches within the same poetic tradition. Even if this tradition shares more than the same type of metric and means of composition.

The poems of the Epic Cycle have more thematic affinity with the Homeric poems. Still, based on the summary that survives of them, on their fragments and the analysis that later authors made of them, a few distinctions were brought to light. The first of them was already mentioned: the extension. The others are related to the epic diction and overall aesthetic qualities ${ }^{46}$.

Despite the differences in type, still, it is important to emphasize that they all shared the same tradition. The resonance between them can be observed from several points of view, but especially from the perspective of shared set of references and by the assumption that the audience or the readers must have had a wider conception of the larger whole that contains all those themes, characters and episodes.

f) The function of tradition: memory; cultural integration; Pan-Hellenism

The broader tradition, as I have presented it here, has a large temporal reach, being a very long-term phenomenon. It also contains varied forms of expression: poetic, of many types; other forms of oral expression; figurative art; religious manifestations; etc.

If we focus on the poetry, as I have been doing here, is it possible to identify the function it fulfilled? A first possibility is that its purpose was a form of entertainment. Poetry has the obvious intent of being aesthetically pleasing and of entertaining audiences or readers. However, its functions do not end there.

It could also serve as a form of conserving collective memory. According to Luce, the activity of the singers was a trusted mechanism of preservation of this memory. In the absence of ample use of writing, the

\footnotetext{
${ }^{46}$ On the subject see Davies (1989: 1-10). It is important to point out that Davies strongly based his arguments on Aristotle and on aesthetic criteria which are markedly anachronistic when applied to the material in question. According to Scodel, many modern scholars have been influenced by the aesthetic dislike that Aristotle and Aristarchus' had against the Cycle. Recently, a few scholars have been trying to move away from similar positions, considering the poems of the Epic Cycle as products not necessarily inferior or secondary, but representative of a wider oral tradition (Scodel, 2011: 501-515).
} 
singers would enact a social function when they transmitted and performed the traditions valued by the community (Luce, 1998: 9) ${ }^{47}$.

This has other consequences. As a mechanism of cultural memory, the poetry would also serve as a form of cultural integration. The tradition it was a part of connected a potentially large and varying geographic space over a long period. If one accepts that the tradition could stably preserve some of its characteristics, this cultural integration would function as well in space as in time. Through poetry, forms of perceiving the past would be transported and shared by communities separated in space and time, but brought together, culturally, by the appreciation of the same poetic tradition.

Approached from a different angle, this notion includes a very important cultural phenomenon called Pan-Hellenism. The phenomenon can be observed in several manifestations, especially from the eighth century onwards. Other than the Greek language, shared for a long time, additional cultural characteristics would start to be shared over this period. A feeling of relative unity and integration is also present, despite the relevance of local elements ${ }^{48}$.

Among those Pan-Hellenic cultural manifestations one could mention a few sanctuaries that began to display this dimension (like Delphi, Delos, Dodona, etc.) and the festivals (like the one in Olympia and others) ${ }^{49}$. The poems of the epic oral tradition, the Iliad and the Odyssey and other variants that circulated at the same time, offered different Greek communities a common ground of stories and divinities, besides a shared language ${ }^{50}$.

It is possible that the cultural memory preserved in poetry could predate the Pan-Hellenic movement that accelerates from the eighth century onwards. As I discussed, this memory could have elements form the Mycenaean past, transported through the Greek Dark Ages.

\footnotetext{
47 Havelock is a very important researcher of this subject. He understands the Homeric poems as expressions of an encyclopedic vision of the world. The Homeric narratives would be constantly in touch with the structure and world-view of the Greek society of its time (Havelock, 1996: 106-108).

48 See Bouvier (2002: 444-445).

${ }^{49}$ See Snodgrass for a survey of the subject (Snodgrass, 1971: 352-435).

50 Nagy's model comprehends the Pan-Hellenic poetry as operating not only on local bases, proper for local audiences. On the contrary, Pan-Hellenic poetry would be the product of an evolutionary synthesis of poetic traditions. What it represented was larger than the local characteristics, for it was not particular to a given place (Nagy, 1990: 54).
} 
If we do not accept its origins on such an ancient context, but on a tradition that started to develop sometime around the end of the Greek Dark Ages, that tradition could well be the product of local manifestations that started to mature parallel to one another, and finally merged as part of the Pan-Hellenic process mentioned above.

g) A stable or ever-changing tradition?

As repeatedly mentioned, the tradition of transmission I presented here can be a complex long-term process. Nevertheless, many problems arise if one decides to discuss it in a wider fashion. The first difficulty relates to the period to which we can assign the composition or fixation of the poems that were preserved within the tradition. I will not deal with this subject in detail here.

For the purposes of this paper, I will only say that, despite how this problem can be approached, one could argue that the poems that were preserved, the Iliad and the Odyssey being prominent among them, can be read as representatives of the tradition as a whole. They are not just a source for the periods they were composed in or fixated. This approach depends on how the problem of the stability within the tradition is regarded.

It is important to emphasize that the means to provide a definitive answer are still lacking. Regarding the poems themselves, there are only a few aspects that allow a researcher to infer the level of stability. The language is one of them. The decipherment of the Linear $\mathrm{B}^{51}$ proved that there are elements of the Mycenaean Greek preserved on the Homeric poems, as well as Aeolic and Ionic archaisms ${ }^{52}$. The very structure of the formulaic system of composition, even if Parry's original theory has been widely criticized and is no longer fully accepted, suggests that such elements can be maintained in more or less stable forms over long periods of time.

When Parry and Lord initiated their comparative studies in the 1930s, using the Yugoslavian oral tradition as a basis, their approach was extremely innovative ${ }^{53}$. Since then, the results of their comparative studies have been substantially criticized. There are clear limits that refer to cultural specificities and differences on the tradition type that should

\footnotetext{
51 See Chadwick (1995).

52 See Nagy (2011: 231-233).

53 The results were published in a more influential manner only in Lord's The Singer of Tales, in 1960.
} 
have been given more attention on both sides of the comparison ${ }^{54}$. Some critics were so virulent that they went so far as to suggest that the fieldwork of collecting and comparing different oral traditions was not useful for the literary analysis of the Homeric poems and the Greek epic tradition at all55. Perhaps Parry and Lord's approach had indeed accepted many elements of the Yugoslavian tradition as possible to generalize to all oral epic traditions. This might be the most fragile aspect of the socalled formulary oral theory in its initial stages.

Notwithstanding, since those attempts many other researchers became interested in similar fieldwork ${ }^{56}$. The multiplication of living traditions being researched made clear, unsurprisingly, that the types of traditional oral forms of composition are as varied as the types of cultures in which those traditions are or were present ${ }^{57}$.

The criticism of Parry and Lord's theories not withstanding, many scholars still maintain the practice of generalizing some elements believed to be related to oral cultures. One of these generalizations is about the level of stability that is allowed within a tradition of this type. A common position states that within an oral tradition, it is only possible to preserve a memory of the past that had elements (social structures, practices and objects) that goes back three generations at the most 58 . This notion is based on the idea that the past can only be reached when there are still living agents that can remember it. In other words, the memory depends on the span of the generations and of social structures that allow grandparents to share experiences with their grandchildren. Some scholars adopt the concept of homeostasis, which postulates that when a tradition tries to say something about its past, elements of the present are also included. More than that, they are far more pervasive than the past that was being aimed at ${ }^{59}$.

\footnotetext{
${ }^{54}$ Comments along these lines can already be found as soon as Kirk (1962) and find echo in many other subsequent scholars.

55 According to Rutherford, Parry's work with living traditions was less valued than his analysis of the formulary system (Rutherfod, 1996: 14).

56 The collections organized by Honko, Handoo and Foley (1998) and by Mundal and Wallendorf (2008) attest that this interest is still strong.

57 The most influential study to argue along this line is still Finnegan's. The author's book makes for an excellent example of how one should avoid generalizations when defining elements of oral poetry. Finnegan defends that a single model of composition in performance is not adequate for all cases (Finnegan, 1977: 69-87).

58 As defended by authors like Raaflaub (1998: 394-396) and Saïd (2011:. 77-79).

59 See Goody and Watt (1968), Ong (1982: 46-49) and Vansina (1965). The same Vansina lists some limitations to the concept, while defending that many social changes lead to addition and not suppression of ancient forms. As such, some older variations are left intact. Besides, even completely suppressed characteristics could at times leave traces (Vansina, 1985: 120-123).
} 
The problem is that the comparative analysis of oral traditions shows a great variety of types and integrant parts. Regarding the stability (that is, of how an oral tradition can preserve and transmit accurately its past and what its reach is), one must consider the importance granted within the tradition to how its transmission works.

The level of fixation of the information being orally transmitted in those traditions (if always recomposed or even memorized word-by-word) varies from tradition to tradition. This element depends on the conception its members (singers, storytellers and audiences) have of what is an accurate transmission, and what is considered stability ${ }^{60}$. An assumption that cannot be taken for granted is the one that postulates that memory is supposedly more limited without the aid of writing as an accurate instrument of stable preservation of extensive information. Such notion is fueled by a commonsense perception of modern day-to-day mnemonic practices. Today, because of the widespread use of writing, one depends less on the exclusive use of memory, and so its potential is less developed ${ }^{61}$.

This is not necessarily true for many exclusively or majorly oral cultures, where the diffusion of writing is inexistent or reduced. In some, more refined mnemonic feats can reach impressive results, for Contemporary Western standards. Moreover, the notion of homeostasis seems to be more focused on how some aspects change over time, in detriment of bringing to the fore elements that might have remained preserved unconsciously or by active effort ${ }^{62}$.

There is no accurate way to measure how stable the Greek tradition of oral epic hexametric composition really was. Even the level of importance given by its agents to the aspect of accurate transmission, or how they understood it, is unknown. For instance, at the linguistic level, there are some stable elements that might connect the poems to a very ancient past. Nevertheless, the reach of this stability is still open to debate. If one considers social structures and institutions that might have been absorbed and preserved on the transmission of the poems, the problem

\footnotetext{
${ }^{60}$ Mundal and Wellendorf comments on the Nordic skaldic poetry are particularly illustrating. This poetic form does not allow for much variation, usually being memorized word-by-word (Mundal; Wellendorf, 2008: 1-2).

${ }^{61}$ Taplin sees on the approach that defends that writing was used in the composition of the Homeric poems a reflection of the profound discredit of memory in the West nowadays. In this context, mnemonic feats like the composition of a greatly structured, organic and planned epic would be considered impossible (Taplin, 1992:. 36).

62 See Malkin (1998: 269-270). According to Scodel, not all traditions are homeostatic (Scodel, 2002: 19).
} 
becomes even more complex. This topic deserves a separate study in itself.

Speculation aside, one must accept the possibility that very long-term characteristics might have been absorbed onto the Homeric poems, especially if one considers the dynamics of composition and cultural integration. I believe this to be the key to any approach to these poems, especially as historical sources. Considered in this light, the Homeric poems would then be taken as witnesses to the broader tradition they are a part of.

If, in some aspects, this tradition displays a large stability that can reach far back to a very ancient past, or if it only denotes a more recent reevaluation of that process, that is still beyond a definite answer. It is one of the main problems of this whole area of studies. Finally, these difficulties do not prevent a historical approach to the Homeric poems, and especially one that takes that takes all this particular characteristics of the tradition into account.

\section{Bibliographic References}

AHL, F.; ROISMAN, H. M. The Odyssey reformed, Ithaca: Cornell University Press, 1996.

AINIAM, A. M. Reflections on Hero Cults in Early Iron Age Greece. In: HÄGG, R. Ancient Greek Hero Cult: Proceedings of the Fifth International Seminar on Ancient Greek Cult. Stockholm: Paul Aströms Förlag, 1999.

ANDERSEN, O.; HUAG, D. (eds.) Relative Chronology in early Greek epic poetry, Cambridge: CUP, 2012.

BOUVIER, D. Le cetre et la lyre: L' Iliade ou les herós de la memoire. Grenoble: Jérôme Millon, 2002.

BRAUDEL, F. História e Ciências Sociais: A longa duração. In: Escritos sobre a história. São Paulo: Editora Perspectiva, 2009. p. 41-78.

BURKERT, W. The making of Homer in the sixth Century B. C.: Rapsodes versus Stesichorus. Papers on the Amasis Painter and His World. Malibu: Paul Getty Museum, 1987, p. 43-62.

CHADWICK, J. The decipherment of linear B. Cambridge: CUP, 1995.

DAVIES, M. The greek epic cycle. Bristol Classical Press. 1989. 
DESBOROUGH, V. R. The greek dark ages. New York: St. Martin Press, 1972.

FINNEGAN, Ruth. Oral poetry: its nature, significance and social context. Cambridge: CUP, 1977.

FORD, A. Homer: the poetry of the past. Cornell: CUP, 1992.

FRANCISCO, Gilberto da Silva. Panatenáicas: tradição, permanência e derivação; Tese, MAE, 2012.

FRIIS JOHANSEN, K. The Iliad and the early greek art. Copenhagen: Munksgaard. 1967.

GIANNANTONI, G. (ed.). I Presecratici: Testimonianze e frammenti. Bari: Laterza, 1993.

GOODY, J.; WATT, L. The Consequences of Literacy. In: Goody, J. (ed.), Literacy

Traditional Societies, edited by J. Goody, pp. 27-68. Cambridge: 1968.

GRAZIOSI, B.; HAUBOLD, J. Homer: the resonance of epic. London: Duckworth, 2005.

GRETHLEIN, J. From 'imperishable glory' to History: the Iliad and the Trojan War. In: KONSTAN, D.; RAAFLAUB, K. A. (org.) Epic and history. Malden-Oxford: Wiley-Blackwell, 2010.

HAVELOCK, E. Prefácio a Platão. Campinas: Papirus, 1996.

HOBSBAWM, E; RANGER, T. (eds.). A invenção das tradições. São Paulo: Paz e Terra, 1997.

HONKO, I.; HANDOO, J.; FOLEY, J. M. (eds.). The Epic - Oral and Written, Mysore: Central Institute of Indian Languages, 1998.

JANKO, R., Homer, Hesiod, and the Hymns: diachronic developments in epic diction. Cambridge: CUP, 1982

JENSEN, M. S. The Homeric question and the oral formulaic theory. Copenhagen: Museum Tusculanum Press, 1980.

KIRK, G. The songs of Homer. Cambridge: CUP, 1962. 
MUNDAL, Else ; WELLENDORF, Jonas. Oral art forms and their passage into writing. Copenhagen: Museum Tusculanum Press, 2008.

LENCLUD, G. Qu'est-ce que la tradition? In: DETIÈNNE, M. (ed.) Transcrire les mythologies. Paris: Albin Michel, p. 25-44, 1994.

LORD, Albert Bates. The singer of tales. Cambridge: Harvard University Press, 1960.

LOWENSTAM, Steve. The Uses of Vase-Depictions in Homeric Studies. Transactions of the American Philological Association (1974-), vol. 122, 1992, p. 165- 198.

Talking Vases: The relationship between the Homeric poems and archaic representations of epic myth. Transactions of the American Philological Association (1974-), v. 127, 1997, p. 21-76.

LUCE, J. V., Homer and the Heroic Age. London: Thames and Hudson, 1975.

. Celebrating Homer's landscape: Troy and Ithaca revised. Yale University Press, 1998.

MALKIN, Irad. The returns of Odysseus: colonization and ethnicity. Berkeley: University of California Press, 1998.

MARCOVICH, M.; MONDOLFO, R.; TARÁN, L. Eraclito: Testimonianze, Imitazioni e Fragmmenti. Milano: Bompiani, 2007.

MONRO, D. B.; ALLEN, T. W. Homeri Opera. Oxford: Claredon Press. $3^{\text {a }}$ edição. 1920.

NAGY, G. Homer's Pindar. Baltimore: Johns Hopkins University, 1990. Homeric Questions. Austin: University of Texas Press, 1996.

2011. . Homer the preclassic. Berkeley: University of California Press,

NILSSON, M. The Mycenaean Origin of Greek Mythology. Cambridge: CUP, 1932.

1993.

Homer and Mycenae. New York: Cooper Square Publishers, Inc.,

ONG, W. J. Orality and Literacy: The technologizing of the world. London: Methuen, 1982. 
OLIVEIRA, Gustavo J. D. Histórias de Homero: Um balanço das propostas de datação dos poemas homéricos. Revista História e Cultura, Franca-SP. V. 1, n. 2, p. 126-147, 2012.

OUTHWAITE, W.; BOTTOMORE, T. Dicionário do pensamento social do século XX. Rio de Janeiro: Jorge Zahar editor, 1996.

PAGE, D. L. History and the Homeric Iliad. Berkley: University of California Press, 1976.

PARRY, Adam. The language of Achilles and other papers. Oxford: OUP, 1989.

PARRY, Milman. Studies in the Epic Technique of Oral Verse-Making I. Homer and Homeric Style. Harvard Studies in Classical Philology, v. 41, 1930, p. 73-147.

Studies in the Epic Technique of Oral Verse-Making II. The Homeric Language as the Language of an Oral Poetry. Harvard Studies in Classical Philology, v. 43, 1932, p. 1-50.

PHILLIPS, M. S.; SCHOCHET, G. (eds.). Questions of Tradition. University of Toronto Press, 2004.

RAAFLAUB, K. A. Homer, the Trojan War, and History. In: BOEDECKER, D. The world of Troy. Washington, DC: Society for the Preservation of the Greek Heritage, 1998.

RUSSO, Joseph. Homer against his tradition. Arion, v. 7, n. 2, 1968.

RUTHERFORD, R. B. Homer. Oxford: OUP, 1996.

SEALEY, R. From Phemios to Ion. Revue des Études Grecques. Tome LXX, p. 312-355, 1957.

POWELL, B. Writing, oral poetry, and the invention of the narrative style in greek art. In: BUITON-OLIVER, D. (ed.) The Odyssey and Ancient Art: an epic in word and image. New York, Bard College, 1992, p. 180-185.

. Homer and the origin of Greek alphabet, Cambridge: CUP, 1996.

SAÏD, S. Homer and the Odyssey. Oxford: OUP, 2011.

SCODEL, R. Listening to Homer: Tradition, narrative and Audience. Michigan: UMP, 2002. 
. Hesiod and the Epic Cycle. In: MONTANARI, F. RENGAKOS, A. TSAGALIS, C. C. (eds.) Homeric contexts: neo analysis and the interpretation of oral poetry. Berlin: De Gruyter, 2011.

SEAFORD, R. Reciprocity and Ritual: Homer and the tragedy of the developing City-state. Oxford: OUP, 1994.

SELIGMAN, E. R.; JOHNSON, A. Encyclopaedia of social Sciences. New York: Macmillan Company, 1957, vol. 15.

SHEAR, I. M. Tales of heroes: the origins of Homeric texts. New York: Aristide D. Caratzas, 2000.

SHIELS, E. Tradition. Chicago, University of Chicago Press, 1981.

SNODGRASS, A. M. The Dark Age of Greece: An Archaeological Survey of the Eleventh to Eighth Centuries B.C. Edinburgh: University Pres, 1971.

Homero e os Artistas: texto e pintura na arte grega antiga. São Paulo: Odysseus Editora, 2004.

TAPLIN, O. Homeric soundings: the shaping of the Iliad. Oxford: Claredon Press, 1992.

THIEL, H. van. Homeri Odyssea. Hildesheim: G. Olms, 1991. Homeri Ilias. Hildesheim: G. Olms, 1996.

TOUCHEFEU-MEYNIER, O. Thèmes odysséens dans l'art antique. Paris: Editions E. de Boccard 1968.

VANSINA, J. Oral tradition: A study in historical methodology. Chicago: Aldine, 1965.

. Oral tradition as history. Wisconsin: UWP. 1985.

VICO, G. Ciência Nova. Calouste Gulbekian, 2005.

WADE-GERY, H. T. The poet of the Iliad. Cambridge: CUP, 1952.

WEST, M. L. Ilias. Vol. I. Stuttgart \& Leipzig: Bibliotheca Teubneriana, 1998.

. Ilias. Vol. II. München \& Leipzig: Bibliotheca Teubneriana, 2000.

. The invention of Homer. Classical quarterly, vol. 49, n. 2, 1999, p.

364-382. 
Rhasodes at Festivals. Zeitschrift für Papyrologie und Epigraphik. Band 173, 2010, p. 1-13. . The making of the Iliad. Oxford: OUP, 2011. . The making of the Odyssey. Oxford: OUP. 2014.

WILAMOWITZ, M. U. V. Homerische Untersuchungen. Berlin: Weidmann, 1991.

WOLF. Prolegomena ad homerum. Princeton: PUP. 1985. 